\title{
Analisis Pengaruh Pembiayaan Dan Simpanan Terhadap Pendapatan BNI Syariah Cabang Pekanbaru
}

\author{
Marina Zulfa ${ }^{1}$, Vievie Ova Kurnia² \\ 1\&2Fakultas Agama Islam Universias Islam Riau (UIR) Pekanbaru \\ Jl. Kaharuddin Nasution No. 113 Perhentian Marpoyan Pekanbaru 28284 \\ e-mail : Marinazulfa@fis.uir.ac.id
}

\begin{abstract}
Abstrak: Penelitian ini dilatar belakangi oleh perkembangan ekonomi saat ini yang semakin pesat, yaitu dengan munculnya lembaga keuangan syariah. Bank Negara Indonesia termasuk salah satu pelopor berdiri dan berkembangnya bank syariah di Indonesia. Produk-produk BNI Syariah yang bervariasi disediakan untuk masyarakat, misalnya simpanan dan pembiayaan. Tujuan dalam penelitian ini adalah untuk mengetahui bagaimana pengaruh pembiayaan dan simpanan secara parsial dan simultan terhadap pendapatan BNI Syariah. Jenis data yang digunakan yaitu data sekunder berupa laporan keuangan BNI Syariah. Analisis data yang digunakan yaitu analisis kuantitatif dimana proses penghitungannya menggunakan SPSS for windows versi 21. Dari hasil uji-F menunjukkan bahwa dari kedua variabel bebas (pembiayaan dan simpanan) secara bersama- sama mempunyai pengaruh yang signifikan terhadap pendapatan BNI Syariah Cabang Pekanbaru. Pembiayaan dan simpanan memiliki hubungan yang sangat kuat terhadap pendapatan BNI Syariah Cabang pekanbaru, ini diketahui dari nilai koefisien korelasi sebesar 98,5\%. Kemudian terdapat kontribusi yang besar antara pembiayaan dan simpanan terhadap pendapatan BNI Syariah Cabang Pekanbaru, hal ini diketahui dari besaran nilai koefisien determinasi yaitu sebesar $96,7 \%$.
\end{abstract}

Kata Kunci: Pembiayaan, Simpanan, Bank Syariah, Pendapatan 


\section{PENDAHULUAN}

Kegiatan ekonomi pada umumnya tidak lepas dari memproduksi, mendistribusi dan mengkonsumsi. Seiring perkembangan zaman populasi manusia mengalami pertumbuhan, sehingga ekonomi yang sudah ada mengalami peningkatan. Bank merupakan salah satu instrumen dari sistem keuangan setiap negara. Bank juga merupakan lembaga keuangan yang tepat bagi perusahaan, badan-badan pemerintahan, swasta maupun perorangan, untuk menyimpan dana melalui kegiatan perkreditan dan berbagai jasa yang diberikan. Perbankan juga memudahkan pertukaran dan membantu modal/pembiayaan yang mencakup hampir semua sektor perekonomian.

Dalam sejarah perekonomian umat Islam, pembiayaan yang dilakukan dengan akad yang sesuai syariah telah menjadi bagian dari tradisi umat Islam sejak zaman Rasulullah SAW. Praktik-praktik seperti menerima titipan harta, meminjamkan uang untuk keperluan konsumtif dan produktif, serta melakukan pengiriman uang, telah lazim dilakukan sejak zaman Rasulullah SAW. Dengan demikian, fungsi utama perbankan, yaitu menerima deposit, menyalurkan dana dan melakukan transfer dana telah menjadi bagianyang tidak terpisahkan dari kehidupan umat Islam, bahkan sejak zaman Rasulullah SAW.

$$
\text { Sebagai lembaga keuangan }
$$

perbankan syariah bertujuan menunjang pelaksanaan pembangunan nasional dalam rangka meningkatkan keadilan, kebersamaan dan pemerataan kesejahteraan rakyat.

Menghimpun dana dari masyarakat dalam bentuk simpanan, artinya dalam hal ini bank menjadi tempat menyimpan uang atau tempat berinvestasi bagi masyarakat. Upaya penghimpunan dana ini harus dirancang sedemikian rupa sehingga dapat menarik minat masyarakat untuk menjadi anggota di Bank Syariah. Prinsip utama dalam manajemen funding ini adalah kepercayaan. Artinya kemauan masyarakat untuk menaruh dananya pada Bank Syariah sangat dipengaruhi oleh tingkat kepercayaan masyarakat terhadap Bank Syariah tersebut.

Dalam kegiatan penyaluran dana bank syariah atau lembaga keuangan syariah lainnya melakukan investasi dan pembiayaan. Disebut investasi karena prinsip yang dilakukan adalah prinsip penanaman dana atau penyertaan, dan keuntungan yang akan diperoleh tergantung pada kinerja usaha yang menjadi objek penyertaan tersebut sesuai dengan nisbah bagi hasil yang telah diperjanjikan sebelumnya. Disebut pembiayaan karena bank syariah atau lembaga syariah menyediakan dana guna membiayai kebutuhan nasabah yang memerlukannya dan layak memperolehnya.

Pembiayaan dapat berupa transaksi bagi hasil, transaksi sewa-menyewa, transaksi jual beli, transaksi pinjam meminjam dan transaksi sewa-menyewa jasa/multijasa. 
Tabel. 1

Pendapatan dari Simpanan BNI Syariah Cabang Pekanbaru Periode Januari 2016- Desember 2017

\begin{tabular}{cccc}
\hline No. & Periode & Tahun 2016 (Rp) & Tahun 2017 (Rp) \\
\hline 1 & Januari & 112.000 .000 & 118.000 .000 \\
2 & Februari & 252.000 .000 & 251.000 .000 \\
3 & Maret & 360.000 .000 & 402.000 .000 \\
4 & April & 532.000 .000 & 481.000 .000 \\
5 & Mei & 577.000 .000 & 588.000 .000 \\
6 & Juni & 710.000 .000 & 685.000 .000 \\
7 & Juli & 869.000 .000 & 782.000 .000 \\
8 & Agustus & 982.000 .000 & 866.000 .000 \\
9 & September & 1.140 .000 .000 & 1.012 .000 .000 \\
10 & Oktober & 1.277 .000 .000 & 1.154 .000 .000 \\
11 & November & 1.341 .000 .000 & 1.278 .000 .000 \\
12 & Desember & 1.454 .000 .000 & 1.478 .000 .000 \\
& Total & 9.606 .000 .000 & 9.095 .000 .000
\end{tabular}

Sumber: Laporan Keuangan BNI Syariah Pekanbaru 2016-2017

Pada tabel di atas dapat kita lihat, bahwa pendapatan dari simpanan tahun 2017 mengalami penurunan dari tahun 2016.
Berikut ini merupakan data total pendapatan BNI Syariah Cabang Pekanbaru yang telah dikurangi beban bagi hasil :

Tabel. 2

Pendapatan BNI Syariah Cabang Pekanbaru Periode Januari 2016- Desember 2017

\begin{tabular}{cccc}
\hline No. & Periode & Tahun 2016 (Rp) & Tahun 2017 (Rp) \\
\hline 1 & Januari & 1.596 .000 .000 & -242.000 .000 \\
2 & Februari & 3.244 .000 .000 & 1.495 .000 .000 \\
3 & Maret & 4.619 .000 .000 & 6.476 .000 .000 \\
4 & April & 6.411 .000 .000 & 8.550 .000 .000 \\
5 & Mei & 8.014 .000 .000 & 9.600 .000 .000 \\
6 & Juni & 9.803 .000 .000 & 11.750 .000 .000 \\
7 & Juli & 11.552 .000 .000 & 13.646 .000 .000 \\
8 & Agustus & 13.282 .000 .000 & 15.746 .000 .000
\end{tabular}




$\begin{array}{cccc}9 & \text { September } & 14.987 .000 .000 & 18.422 .000 .000 \\ 10 & \text { Oktober } & 16.838 .000 .000 & 20.549 .000 .000 \\ 11 & \text { November } & 18.705 .000 .000 & 22.660 .000 .000 \\ 12 & \text { Desember } & 20.734 .000 .000 & 25.117 .000 .000 \\ & \text { Total } & 129.785 .000 .000 & 153.769 .000 .000\end{array}$

Sumber: Laporan Keuangan BNI Syariah Pekanbaru 2016-2017

Dari tabel di atas dapat dilihat dan kegiatan distribusi barang dan jasa bahwa total pendapatan BNI Syariah (Soemitra, 2010: 28).

Cabang Pekanbaru setiap bulannya Macam-Macam Lembaga Keuangan

mengalami peningkatan.

Guna mengetahui seberapa besar pengaruh pembiayaan dan simpanan terhadap pendapatannya, dan mana yang lebih diminati masyarakat atau mana yang lebih unggul, dan jenis pembiayaan atau simpanan apakah yang mempengaruhi pendapatan BNI Syariah Pekanbaru, maka terdapat beberapa rumusan masalah yang diangkat yaitu pengaruh pembiayaan terhadap pendapatan BNI Syariah Cabang Pekanbaru dari periode Januari 2016Desember 2017, pengaruh simpanan terhadap pendapatan BNI Syariah Cabang Pekanbaru dari periode Januari 2016Desember 2017, dan pengaruh pembiayaan dan simpanan secara simultan terhadap pendapatan BNI Syariah Cabang Pekanbaru dari periodeJanuari 2016- Desember 2017.

\section{TINJAUAN PUSTAKA}

\section{Lembaga Keuangan}

Menurut SK Menkeu RI No 792 Tahun 1990, lembaga keuangan adalah semua badan yang kegiatannya bidang keuangan, melakukan penghimpunan dan penyaluran dana kepada masyarakat terutama guna membiayai investasi perusahaan. Meski dalam peraturan tersebut lembaga keuangan diutamakan untuk membiayai investasi perusahaan, namun tidak berarti membatasi kegiatan pembiayaan lembaga keuangan. Dalam kenyataannya, kegiatan usaha lembaga keuangan bisa diperuntukkan bagi investasi perusahaan, kegiatan konsumsi
Menurut Burhanuddin (2010:16) lembaga keuangan dapat dibagi menjadi dua yaitu:

a. Lembaga Keuangan Bank (LKB)

Institusi perbankan merupakan subsistem yang keberadaan lembaga keuangan (financial institution). Menurut hukum perbankan yang berlaku saat ini, Indonesia adalah negara yang menganut konsep perbankan Nasional dengan sistem ganda (dual bankingsystem). Artinya bahwa selain ada perbankan konvensional yang beroperasi berdasarkan sistem bung, ada juga perbankan lain yang menjalankan kegiatan usahanya berdasarkan prinsipprinsip syariah. Meskipun keduanya sama-sama lembaga perbankan, namun baik secara konsep maupun implementasinya tetap berbeda antara satu dengan lainnya. Dalam hukum bisnis syariah, penegasan adanya perbedaan diantara keduanya sangatlah diperlukan, terutama dimaksudkan untuk mengetahui sebab halal-haramnya, serta akibat maslahat-mudharatnya.

b. Lembaga Keuangan Bukan Bank (LKBB)

Lembaga Keuangan Bukan Bank (LKBB) adalah semua badan usaha yang melakukan kegiatan di bidang keuangan, baik secara langsung atau tidak langsung menghimpun dana terutama dengan jalan mengeluarkan kertas berharga dan menyalurkan dalam masyarakat terutama guna membiayai 
investasi perusahaan. Contoh Lembaga Keuangan Bukan Bank (LKBB) yaitu pegadaian, koperasi, perusahaan modal ventura, perusahaan sewa guna, pasar modal, perusahaan asuransi dan dana pensiun.

\section{Bank Syariah}

Pengertian bank syariah secara umum adalah bank yang pengoperasiannya disesuaikan dengan prinsip syariat Islam (Rivai dan Arviyan Arivin, 2010: 32).

Bank Syari'ah, adalah bank yang beroperasi dengan tidak mengandalkan pada bunga, dan juga disebut dengan lembaga keuangan/ perbankan yang opersional dan produknya dikembangkan berlandaskan pada Alquran dan Hadist Nabi SAW. Atau dengan kata lain, bank syari'ah tersebut adalah lembaga keuangan yang usaha pokoknya memberikan pembiayaan dan jasa-jasa lainnya dalam lalu lintas pembayaran serta peredaran uang yang pengoperasiannya disesuaikan dengan prinsip syari'at Islam (Rusby. Dkk, 2020 : 36).

Pasal 1 ayat 7 Undang-Undang No. 21 Tahun 2008 memberikan pengertian bahwa yang dimaksud bank syariah adalah bank yang menjalankan kegiatan usahanya berdasarkan prinsip syariah dan menurut jenisnya terdiri atas Bank Umum Syariah dan Bank Pembiayaan Rakyat Syariah (Lestari, 2015: 112).

\section{Fungsi Bank Syariah}

Berdasarkan Pasal 4 UU No. 21 Tahun 2008 tentang Perbankan Syariah, disebutkan bahwa bank syariah wajib menjalankan fungsi menghimpun dan menyalurkan dana masyarakat. Bank Syariah juga dapat menjalankan fungsi sosial dalam bentuk lembaga baitulmal, yaitu menerima dana yang berasal dari zakat, infak, sedekah, hibah, atau dana sosial lainnya (antara lain denda terhadap nasabah atau ta "zir) dan menyalurkan kepada orgnisasi pengelola zakat. Selain itu, bank syariah juga dapat menghimpun dana sosial yang berasal dari wakaf uang dan menyalurkannya kepada pengelola wakaf (nazhir) sesuai dengan kehendak pemberi wakaf.

Produk Bank Syariah

Produk dan jasa keuangan syariah yang ditawarkan bank syariah di Indonesia cukup bervariasi. Menurut Ascarya (2008) produk dan jasa tersebut meliputi Produk Pendanaan, Produk Pembiayaan, dan Jasa Perbankan (Melina, 2018:53)

\section{Pembiayaan}

Pembiayaan merupakan aktivitas bank syariah dalam menyalurkan dana kepada pihak lain selain bank berdasarkan prinsip syariah. Penyaluran dana dalam bentuk pembiayaan didasarkan pada kepercayaan yang diberikan oleh pemilik dana kepada pengguna dana. Pemilik dana percaya kepada penerima dana, bahwa dana dalam bentuk pembiayaan yang diberikan pasti akan terbayar. Penerima pembiayaan mendapat kepercayaan dari pemberi pembiayaan, sehingga penerima pembiayaan berkewajiban untuk mengembalikan pembiayaan yang telah diterimanya sesuai dengan jangka waktu yang telah diperjanjikan dalam akad pembiayaan (Dahlan, 2012:160).

\section{Jenis-Jenis Pembiayaan}

Pembiayaan pada dasarnya diberikan atas dasar kepercayaan. Dengan demikian pemberian pembiayaan sama artinya dengan memberi kepercayaan. Hal ini berarti kepercayaan yang diberikan benar-benar harus diyakini dapat dikembalikan oleh penerima pembiayaan sesuai dengan waktu dan syarat yang telah disepakati bersama. Menurut Rivai dan Andria Pemata Veithzal (2008: 9-10) dilihat dari tujuannya jenis pembiayaan dibagi menjadi dua yaitu Pembiayaan Konsumtif dan Pembiayaan Produktif.

\section{Simpanan}

Simpanan adalah dana yang dipercayakan oleh nasabah kepada bank syariah berdasarkan akad wadi" $a h$ atau akad lain yang tidak bertentangan dengan 
prinsip syariah dalam bentuk giro, tabungan atau bentuk lainnya yang dipersamakan dengan itu. (Soemitra, 2010: 74)

Pengertian simpanan menurut undang-undang No. 7 Tahun 1992 pasal 1 (5) yaitu: simpanan adalah dana yang dipercayakan oleh masyarakat kepada bank berdasarkan perjanjian penyimpanan dana dalam bentuk giro, deposito, sertifikat deposito, tabungan dan atau bentuk lainnya yang dipersamakan dengan itu.

Jenis-Jenis Simpanan

Secara umum jenis simpanan terbagi menjadi tiga, yaitu Simpanan Giro, Simpanan Tabungan, dan Simpanan Deposito

\section{Pendapatan}

Menurut buku istilah Ekonomi Syariah, pendapatan adalah semua penerimaan, baik tunai maupun bukan tunai yang merupakan hasil dan penjualan barang atau jasa dalam jangka waktu tertentu (income, revenue) (Sholihin, 2010: 621).

\section{Jenis-Jenis Pendapatan Bank Syariah}

Berikut akan dijelaskan mengenai jenis-jenis pendapatan bank syariah menurut Cahyani dan Morita (Zulfa, 2019: 1).

a. Pendapatan Operasional Utama 1) Marjin Murabahah. 2) Pendapatan bagi hasil Mudharabah dan Musyarakah. 3) Pendapatan sertifikat Wadiah Bank Indonesia.

b. Pendapatan Operasional Lainnya, terdiri dari: 1) Pendapatan jual beli surat berharga. 2) Pendapatan administrasi.

c. Pendapatan Non-Operasional. Pendapatan non-operasional diperoleh melalui keuntungan pelepasan aktiva, hibah atau piutang yang sudah dianggap tak tertagih, tetapi akhirnya nasabah mampu melunasi piutangnya.

\section{METODE PENELITIAN}

Penelitian ini dilakukan di BNI Syariah Cabang Pekanbaru yang berada di Jl. Jenderal Sudirman No. 484, Jadirejo, Sukajadi, Kota Pekanbaru, Riau. Penelitian ini dilakukan pada bulan Februari 2018 sampai bulan Mei 2018.

Jenis penelitian yang digunakan pada penelitian ini adalah jenis penelitian kausalitas, yaitu penelitian yang disusun untuk meneliti kemungkinan adanya hubungan sebab-akibat antar variabel (Sanusi, 2017:15). Yaitu meneliti pengaruh hubungan sebab akibat antara pembiayaan dan pendapatan BNI Syariah Cabang Pekanbaru.

\section{HASIL DAN PEMBAHASAN Uji Multikolinearitas}

Uji multikolonieritas bertujuan untuk menguji apakah dalam model regresi ditemukan adanya korelasi antar variabel bebas (independent) atau tidak. Model regresi yang baik seharusnya tidak terjadi korelasi di antara variabel bebas.

Pengujian multikolonieritas dapat dilakukan dengan melihat nilai inflation factor (VIF). Adanya multikolonieritas dapat diketahui jika nilai VIF $>10$. Hasil uji multikolinieritas dapat dilihat pada tabel dibawah ini:

Tabel. 3

\begin{tabular}{|c|c|c|c|c|c|c|c|}
\hline \multirow{3}{*}{ Model } & \multirow{2}{*}{\multicolumn{2}{|c|}{$\begin{array}{l}\text { Unstandardized } \\
\text { Coefficients }\end{array}$}} & \multirow{3}{*}{$\begin{array}{c}\text { Standardized } \\
\text { Coefficients } \\
\text { Beta }\end{array}$} & \multirow{3}{*}{$\mathrm{T}$} & \multirow{3}{*}{ Sig. } & \multirow{2}{*}{\multicolumn{2}{|c|}{ Collinearity Statistics }} \\
\hline & & & & & & & \\
\hline & B & Std. Error & & & & Tolerance & VIF \\
\hline (Constant) & 11,871 & 3,831 & & 3,099 & ,005 & & \\
\hline \multicolumn{8}{|l|}{$\begin{array}{l}\text { Pembiayaan } \\
\text { Simnanan }\end{array}$} \\
\hline & 2,460 & 150 & 1,534 & 16,412 & ,000 & 162 & 6,158 \\
\hline
\end{tabular}




\begin{tabular}{lllllll}
\hline$-2,221$ & 326 &,- 637 & $-6,815$ &, 000 &, 162 & 6,158
\end{tabular}

\section{Sumber: Data Olahan IBM SPSS Statistics 21}

Berdasarkan tabel di atas dapat diketahui bahwa nilai VIF seluruh variabel < 10 dan tolerance $>0,10$. Dengan demikian maka dapat diketahui bahwa tidak ada multikolonieritas dalam model regresi.

\section{Uji Heteroskedastisitas}

Pengujian heteroskedastisitas digunakan untuk menguji apakah model regresi terjadi kesamaan varian dari residual suatu periode pengamatan ke periode pengamatan yang lain. Metode yang digunakan untuk mendeteksi heterokedasitas dapat dilakukan dengan melihat Scatterplot. Jika Scatterplot membentuk pola tertentu yang jelas maka regresi mengalami gangguan heterokedastisitas. Hasil uji heterokedastisitas dapat dilihat pada gambar berikut.

Gambar 1. Hasil Uji Heterokedastisitas

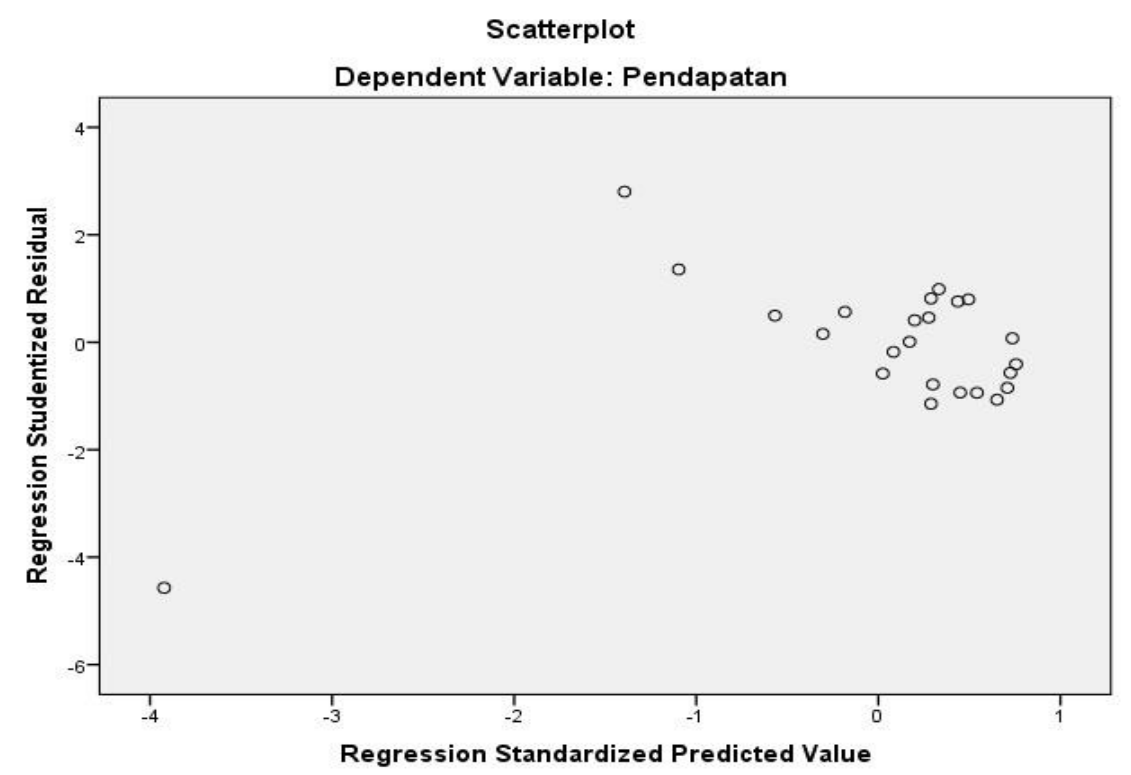

Sumber: Data Olahan IBM SPSS Statistics 21

Berdasarkan gambar di atas dapat dilihat Scatterplot tidak membentuk pola tertentu (menyebar). Dapat disimpulkan bahwa tidak terdapat heterokedastisitas dalam model regresi.

\section{Uji Normalitas}

Uji normalitas bertujuan untuk menguji apakah dalam model regresi, variabel memiliki distribusi normal. Model regresi yang baik adalah jika model regresi memiliki distrisbusi normal atau mendekati normal.
Cara untuk mendeteksi apakah residual berdistribusi normal atau tidak yaitu dengan melihat grafik normal. Jika pola menunjukkan penyebaran titik-titik di sekitar garis diagonal, dan mengikuti arah garis diagonal mengindikasikan model regresi memenuhi asumsi normalitas. Hasil uji normalitas dapat dilihat pada berikut. 
Gambar. 2 Hasil Uji Normalitas

Normal P-P Plot of Regression Standardized Residual

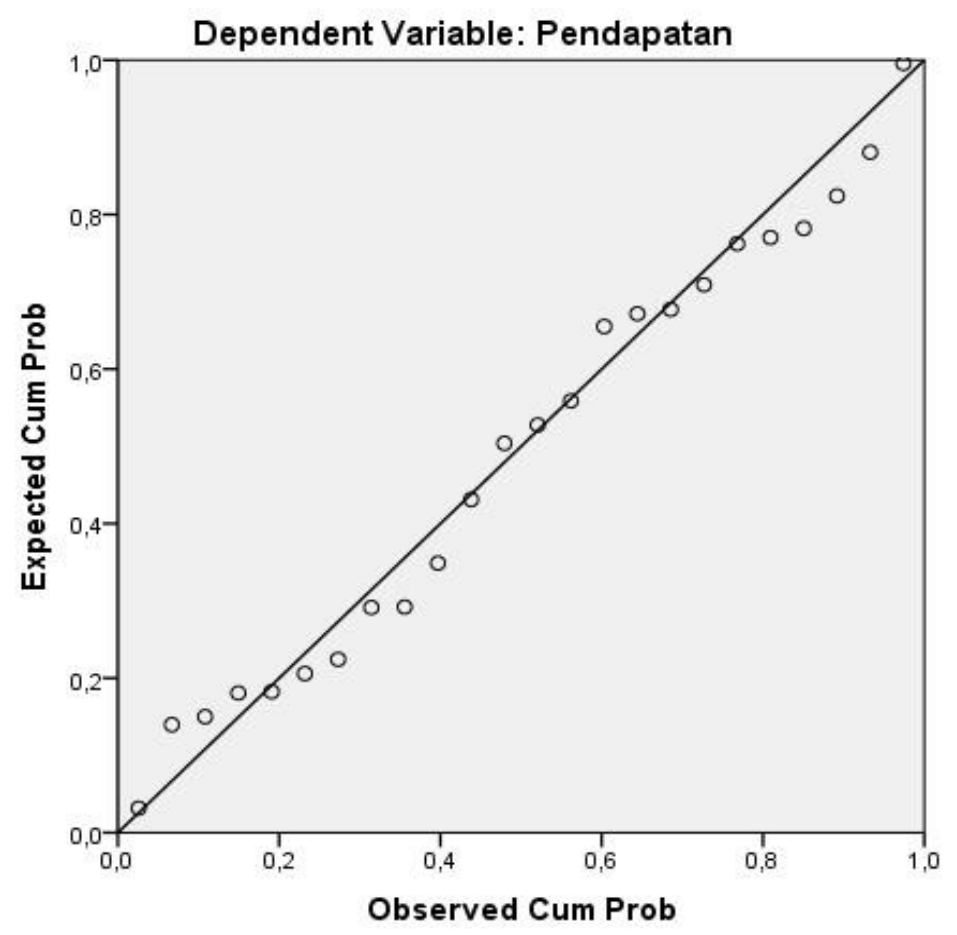

Sumber: Data Olahan IBM SPSS Statistics 21

Berdasarkan gambar di atas, dapat dilihat bahwa data menyebar disekitar garis diagonal dan mengikuti arah garis diagonal pada grafik histogram, hal ini menunjukkan bahwa pola distribusi normal. Jadi dapat disimpulkan bahwa berdasarkan garfik $P-P$ plot, model regresi memenuhi asumsi normalitas.

\section{Analisis Regresi Berganda}

Hasil perhitungan analisis regresi linier berganda melalui IBM SPSS Statistics 21 maka diperoleh nilai-nilai untuk variabel bebas dan variabel terikat dapat dilihat pada tabel berikut:

Tabel 4. Analisis Regresi Berganda

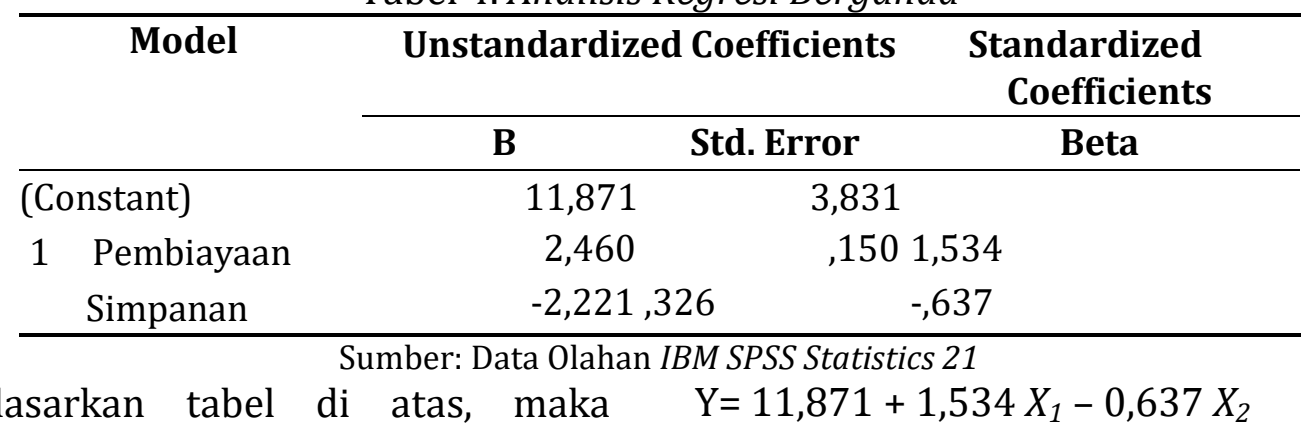

dapat disusun persamaan regresi berganda sebagai berikut:

Arti angka-angka dalam persamaan $\mathrm{Y}=\mathrm{a}+b_{1} X_{1}+b_{2} X_{2}$ regresi diatas adalah: 
a) Nilai konstanta (a) sebesar 11,871. Artinya apabila pembiayaan dan simpanan diasumsikan nol (0), maka Pendapatan BNI Syariah (Y) bernilai $11,871$.

b) Nilai koefisien regresi variabel Pembiayaan $\left(\mathrm{X}_{1}\right)$ sebesar 1,534. Artinya adalah bahwa setiap peningkatan faktor Pembiayaan sebesar 1\% maka akan meningkat Pendapatan BNI Syariah (Y) sebesar 1,534 dengan asumsi $\mathrm{X}_{2}$ tetap.

c) Nilai koefisien regresi variabel Simpanan $\left(\mathrm{X}_{2}\right)$ sebesar -0,637. Artinya adalah bahwa setiap peningkatan faktor Simpanan sebesar 1\% akan mengalami penurunan Pendapatan BNI Syariah (Y) sebesar 0,637 dengan asumsi $X_{1}$ tetap.

\section{Uji Parsial (Uji-t)}

Uji-t dilakukan untuk mengetahui faktor mana yang paling dominan antara variabel bebas dan variabel terikat dengan menggunakan uji parsial (uji-t) dengan menggunakan bantuan program IBM SPSS Statistis 21, maka dapat dilihat tabel dibawah ini:

Tabel 5. Perhitungan Uji-t

\begin{tabular}{|c|c|c|c|c|c|c|}
\hline & \multirow[t]{2}{*}{ Model } & \multicolumn{2}{|c|}{$\begin{array}{r}\text { Unstandardized } \\
\text { Coefficients }\end{array}$} & \multirow{2}{*}{$\begin{array}{c}\begin{array}{c}\text { Standardized } \\
\text { Coefficients }\end{array} \\
\text { Beta }\end{array}$} & \multirow[t]{2}{*}{$\mathbf{t}$} & \multirow[t]{2}{*}{ Sig. } \\
\hline & & B & Std. Error & & & \\
\hline \multirow{3}{*}{1} & (Constant) & & & & 3,099 & ,005 \\
\hline & Pembiayaan & & & 1,534 & 16,412 & ,000 \\
\hline & Simpanan & & &,- 637 & $-6,815$ & , 000 \\
\hline
\end{tabular}

Sumber: Data Olahan IBM SPSS Statistics 21

Dari pengolaan data diatas dapat diketahui bahwa :

a) Nilai $t_{\text {hitung }}$ variabel Pembiayaan $\left(\mathrm{X}_{1}\right)$ sebesar 16,412 dan nilai $t_{\text {tabel }}$ sebesar 2,079 dengan tingkat signifikan 0,05 dan derajat keabsahan sebesar 21 (dk=n-k-1 atau 24-2-1) maka akan terlihat bahwa: $t_{\text {hitung }}>t_{\text {tabel }}$ atau $16,412>2,079$. Hal ini menunjukkan bahwa $\mathrm{H}_{0}$ ditolak dan dan $\mathrm{H}_{1}$ diterima, sehingga dapat dikatakan bahwa pembiayaan memiliki pengaruh positif dan signifikan terhadap Pendapatan BNI Syariah Cabang Pekanbaru.

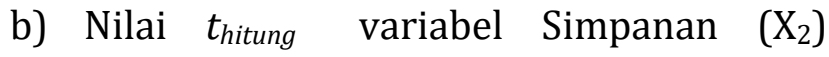
sebesar $-6,815$ dan nilai $t_{\text {tabel }}$ sebesar 2,079 dengan nilai signifikan sebesar

Tabel 6. Perhitungan Uji-F

\begin{tabular}{|c|c|c|c|c|c|}
\hline Model & Sum of Squares & Df & Mean Square & $\mathbf{F}$ & Sig. \\
\hline Regression & 59,512 & 2 & 29,756 & 341,967 &, $000^{\mathrm{b}}$ \\
\hline 1 Residual & & & & & \\
\hline
\end{tabular}

0,000 pada tingkat signifikan 0,05 dan derajat keabsahan sebesar 21 (dk=n-k-1 atau 24-2-1) maka akan terlihat bahwa: $t_{\text {hitung }}<t_{\text {tabel }}$ atau $-6,815<2,079$. Hal ini menunjukkan bahwa $\mathrm{H}_{0}$ diterima dan $\mathrm{H}_{2}$ ditolak, sehingga dapat dikatakan bawa simpanan memiliki pengaruh negatif dan signifikan terhadap pendapatan BNI Syariah Cabang Pekanbaru.

\section{Uji Simultan (Uji F)}

Uji-F digunakan untuk mengetahui pengaruh masing-masing variabel bebas terhadap variabel terikat. Hasil pengujian Uji-F tersebut adalah sebagai berikut: 


\begin{tabular}{llll}
\hline Total &, 827 & 1 & 087 \\
& & & \\
& 1,339 & 3 & \\
& & & \\
\hline
\end{tabular}

Sumber: Data Olahan IBM SPSS Statistics 21

Dari tabel diatas menunjukkan bahwa $F_{\text {hitung }}$ sebesar 341,967 sedangkan $F_{\text {tabel }}$ pada taraf signifikan 0,05 dengan df 1 sebesar 2(k-1=3-1), df 2 sebesar 21 (n-k1=24-2-1), maka $F_{\text {tabel }}$ diperoleh sebesar 3,466. Maka $\mathrm{F}_{\text {hitung }}>\mathrm{F}_{\text {tabel }}$ yaitu 341,967 > 3,466 yang berarti bahwa $\mathrm{H}_{0}$ ditolak. Artinya adalah bahwa variabel independen (Pembiayaan dan Simpanan) secara bersama-sama berpengaruh signifikan terhadap variabel dependen (Pendapatan BNI Syariah).

\section{Koefisien Korelasi}

Untuk mengetahui hubungan antar variabel bebas terhadap variabel terikat, maka digunakan analisis korelasi dengan menggunakan bantuan komputer program IBM SPSS Statistics 21 maka dapat dilihat pada tabel dibawah ini:

Tabel 7. Analisis Korelasi

\begin{tabular}{|c|c|c|c|c|}
\hline Model & $\mathbf{R}$ & R Square & Adjusted R Square & $\begin{array}{l}\text { Std. Error of the } \\
\text { Estimate }\end{array}$ \\
\hline 1 &, $985^{\mathrm{a}}$ & ,970 & ,967 & 29498 \\
\hline
\end{tabular}

Nilai R menunjukkan korelasi ganda antar variabel independen dengan variabel dependen. Dari tabel diatas diketahui nilai $\mathrm{R}$ sebesar 0,985 atau sebesar 98,5\%. Artinya adalah bahwa korelasi ganda antara variabel $\mathrm{X}$ (Pembiayaan dan Simpanan) dengan variabel Y (Pendapatan BNI Syariah) memiliki hubungan yang sangat kuat.

\section{Koefisien Determinasi}

Diketahui nilai Adjusted $\mathrm{R}$ Square sebesar 0,967 menunjukkan bahwa sumbangan pengaruh variabel independen (Pembiayaan dan Simpanan) terhadap variabel dependen (Pendapatan BNI Syariah) adalah sebesar 96,7\%. Sedangkan sisanya sebesar 3,3\% dipengaruhi oleh variabel lain yang tidak dimasukkan dalam model ini.

\section{PEMBAHASAN}

Berdasarkan hasil penelitian diatas diketahui bahwa faktor-faktor yang mempengaruhi pendapatan BNI Syariah Cabang Pekanbaru adalah faktor pembiayaan yang terdiri dari pembiayaan murabahah, pembiayaan ijarah, pembiayaan mudharabah, pembiayaan musyarakah dan IMBT. Faktor simpanan terdiri dari giro, tabungan dan deposito.

Analisis data yang digunakan dalam penelitian ini adalah metode kuantitatif yaitu menganalisis secara statistik guna melakukan uji penelitian terhadap data-data yang diperoleh dengan menggunakan analisis regresi linier berganda. Hal ini dilakukan unutk mengukur pengaruh antara variabel bebas (pembiayaan dan simpanan) terhadap variabel terikat (pendapatan BNI Syariah) dan proses perhitungan datanya menggunakan SPSS versi 21.0.

Berdasarkan hasil penelitian diatas diketahui bahwa faktor-faktor yang mempengaruhi pendapatan BNI Syariah Cabang Pekanbaru adalah faktor pembiayaan 
yang terdiri dari pembiayaan murabahah, pembiayaan ijarah, pembiayaan mudharabah, pembiayaan musyarakah dan IMBT. Faktor simpanan terdiri dari giro, tabungan dan deposito.

Analisis data yang digunakan dalam penelitian ini adalah metode kuantitatif yaitu menganalisis secara statistik guna melakukan uji penelitian terhadap data-data yang diperoleh dengan menggunakan analisis regresi linier berganda. Hal ini dilakukan unutk mengukur pengaruh antara variabel bebas (pembiayaan dan simpanan) terhadap variabel terikat (pendapatan BNI Syariah) dan proses perhitungan datanya menggunakan SPSS versi 21.0.

Sebelum memasuki topik pembahasan, penulis mengemukakan kembali apa itu pembiayaan dan simpanan. Menurut Rivai dan Arviyan Arifin (2010:681) pembiayaan adalah pendanaan yang diberikan oleh suatu pihak kepada pihak lain untuk mendukung investasi yang telah direncanakan, baik dilakukan sendiri maupun lembaga. Menurut Soemitra (2010: 74) simpanan adalah dana yang diperayakan oleh nasabah kepada bank syariah berdasarkan akad wadi'ah atau akad lain yang tidak bertentangan dengan prinsip syariah dalam bentuk giro, tabungan atau bentuk lainnya yang dipersamakan dengan itu. Sedangkan yang dimaksud dengan pendapatan menurut Sholihin (2010:621) adalah semua penerimaan, baik tunai maupun bukan tunai yang merupakan hasil dan penjualan barang atau jasa dalam jangka waktu tertentu.

Dan berdasarkan hasil hipotesis diketahui bahwa; 1) terdapat pengaruh yang signifikan antara pembiayaan terhadap pendapatan BNI Syariah; 2) terdapat pengaruh yang signifikan antara simpanan terhadap pendapatan BNI Syariah.

Maka secara parsial dapat diketahui bahwa variabel bebas yang mempunyai pengaruh dominan mempengaruhi pendapatan BNI Syariah Cabang Pekanbaru adalah pembiayaan $\left(\mathrm{X}_{1}\right)$ sebesar 16,412 .

Dari hasil uji-F menunjukkan bahwa pembiayaan dan simpanan (secara simultan) memiliki pengaruh yang signifikan terhadap pendapatan BNI Syariah Cabang Pekanbaru.

Hubungan antara faktor pembiayaan dan faktor simpanan dengan pendapatan BNI Syariah termasuk dalam kategori memiliki hubungan yang sangat kuat, hal ini dapat diketahui dari nilai koefisien korelasi (R) sebesar 98,5\% dan sisanya 1,5\% dipengaruhi oleh variabel lain yang tidak diikut sertakan dalam penelitian ini.

Pengaruh variabel independen (pembiayaan dan simpanan) terhadap variabel dependen (pendapatan BNI Syariah)yang dapat diketahui dari koefisien determinasi (Adjust $R$ Square) sebesar 96,7\% sedangkan sisanya sebesar $3,3 \%$ dipengaruhi oleh variabel lain yang tidak diikutsertakan dalam penelitian ini. Berdasarkan penelitian terdahulu yaitu penelitian Aguspian (2012) yang berjudul "Analisis Pembiayaan Mudharabah Terhadap Tingkat Profitabilitas Pada Bank Sulselbar Cabang Syariah Makassar" menunjukkan kesamaan dengan hasil penelitian yang penulis lakukan, bahwa pembiayaan secara parsila memiliki pengaruh signifikan terhadap pendapatan Bank Syariah.

\section{SIMPULAN}

Berdasarkan hasil pembahasan yang telah diuraikan sebelumnya yang membahas pengaruh pembiayaan dan simpanan terhdap pendapatan BNI Syariah Cabang Pekanbaru, maka dapat diambil beberapa kesimpulan sebagai berikut:

1 Dari hasil uji parsial diketahui bahwa terdapat pengaruh yang signifikan antara pembiayaan dan simpanan terhadap pendapatan BNI Syariah Cabang Pekanbaru. Pada simpanan terjadi pengaruh negatif dan signifikan karena simpanan itu tidak menghasilkan 
pendapatan bagi BNI Syariah Cabang Pekanbaru. Justru pihak bank lah yang memberikan bagi hasil kepada nasabah, dan dikatakan signifikan karena pengaruh nya berdampak langsung terhadap penurunan pendapatan BNI Syariah Cabang Pekanbaru.

2 Dari uji simultan dapat disimpulkan bahwa terdapat pengaruh yang signifikan antara faktor pembiayaan dan faktor simpanan terhadap pendapatan BNI Syariah Cabang Pekanbaru. Sedangkan hasil koefisien korelasi menyatakan bahwa ada hubungan yang sangat kuat antara pembiayaan dan simpanan terhadap pendapatan BNI Syariah Cabang Pekanbaru.

3 Adapun hasil koefisien determinasi menunjukkan bahwa terdapat nilai kontribusi yang besar antara pembiayaan dan simpanan terhadap pendapatan BNI Syariah Cabang Pekanbaru dan sisanya dipengaruhi oleh faktor lain yang tidak termasuk dalam penelitian ini.

\section{DAFTAR RUJUKAN}

Aguspian. (2012). Analisis Pembiayaan Mudharabah Terhadap Tingkat Profitabilitas Pada Bank Sulselbar Cabang Syariah Makassar. Universitas Islam Negeri Alauddin Makassar.

Burhanuddin. (2010). Aspek Hukum Lembaga Keuangan Syariah. Yogyakarta: Graha Ilmu.

Dahlan, A. (2012). Bank Syariah Teoritik, Praktik, Kritik. Yogyakarta: Teras.

Melina, F. (2018). Pembiayaan Pinjaman Lunak Usaha Kecil Ikan Patin dengan PT. Telkom Pekanbaru Melalui Mitra Binaan Menurut Ekonomi Islam. Syarikat: Jurnal Rumpun Ekonomi Syariah, 1(1), 53.

Lestari, Nur Melinda. (2015). Sistem Pembiayaan Bank Syariah
Berdasarkan UU No. 21 Tahun 2008. Jakarta: Grafindo

Zulfa, M. (2019). Analisis Persepsi Masyarakat Industri Kecil Terhadap Pelaksanaan Pembiayaan Bagi Hasil Bank Riau Kepri Cabang Syariah Pekanbaru. Jurnal Tabarru': Islamic Banking and Finance, 2(1), 1.

Rivai, Veithzal dan Andria Permata Veithzal. (2008). Islamic Financial Management. Jakarta: Grafindo.

Rivai, Veithzal dan Arviyan Arifin. (2010). Islamic Banking Sebuah Teori, Konsep dan Aplikasi. Jakarta: Bumi Aksara.

Rusby, Z., Arif, M., \& Hidayatullah, A. (2020). Sistem Penilaian Prestasi Kerja pada PT. Bank Negara Indonesia (Persero) Tbk Kantor Cabang Syari'ah Pekanbaru, Riau. COSTING : Journal of Economic, Business and Accounting, 4(1), 34-43.

Sanusi, Anwar. (2017). Metodologi Penelitian Bisnis. Jakarta: Salemba Empat.

Sholihin, Ahmad Ifham. (2010). Buku Pintar Ekonomi Syariah. Jakarta: Gramedia.

Soemitra, Andri. (2010). Bank dan Lembaga Keuangan Syariah. Jakarta: Prenada Media. 